Anna Deredas, Alicja Piotrowska

Uniwersytet Łódzki

Wydział Filozoficzno-Historyczny

Instytut Etnologii i Antropologii Kulturowej

\title{
DZIENNIK TERENOWY. ZAPIS STAWANIA SIĘ BADACZEM
}

W niniejszym artykule chcemy zaprezentować wynik naszej pracy dydaktycznej ze studentami pierwszego roku etnologii. Podczas ćwiczeń terenowych zaproponowałyśmy im prowadzenie dzienników terenowych, tak by przez utrwalanie doświadczenia terenowego $\mathrm{w}$ tej formie mogli oni z większą samoświadomością uczestniczyć w procesie „stawania się” badaczem. Poddając analizie i interpretacji treści uzyskane z tego rodzaju opisów spróbujemy prześledzić najważniejsze obszary tego specyficznego, bo pierwszego, pobytu w terenie. Materiały terenowe pochodzą z badań prowadzonych przez nas w ciągu dwóch lat, z 15-osobowymi grupami studentów, którzy zapisali się na ten wyjazd do Krynicy Górskiej (2012 i 2013) i Ochotnicy Dolnej (2010 i 2012). Jako doktorantki byłyśmy współprowadzącymi te ćwiczenia wraz z odpowiednio dr. Marcinem Piotrowski oraz dr. Pawłem Schmidtem.

\section{Teren, dziennik, dydaktyka}

Teren, badania terenowe, praca terenowa, doświadczenie terenowe, wyjście w teren, powrót z terenu... te i jeszcze kilka zbliżonych określeń przynależą do profesjonalnego słownika etnologów ${ }^{1}$. Nie wyobrażamy sobie mówić, pisać czy nawet myśleć o etnologii, bez uwzględnienia tej kategorii. Jeżeli zapytamy antropologa o specyfikę dziedziny, którą uprawia najprawdopodobniej wskaże on właśnie na badania terenowe, jako przestrzeń

${ }^{1}$ W niniejszym tekście będziemy używać synonimicznie określeń etnologia/etnolog oraz antropologia/antropolog. 
poznania i doświadczania wpływającą na wygląd uprawianej dyscypliny. Teren, szeroko rozumiany, konstytuuje, uprawomocnia, ale również wytwarza „materię”, którą badacz poddaje interpretacji. Rodzi to wśród etnologów przekonanie, że praca terenowa jest tym, co stanowi o tożsamości tej dyscypliny, o jej wyjątkowości i odrębności względem innych nauk humanistycznych czy też społecznych ${ }^{2}$. Jednakże obecnie pojęcie terenu uległo znacznemu poszerzeniu ${ }^{3}$. Teren przestaje być pojmowany, jako fizycznie istniejący obszar, a praca w nim, jako relacja między badaczem i badanym. Tym metaforycznym terenem staje się tekst, pytanie, problem badawczy. W tradycyjnym ujęciu natomiast:

Badania terenowe zazwyczaj zakładają fizyczne opuszczenie „swojego domu” ("home” - jakkolwiek byłby on zdefiniowany), by podróżować „do” i „z” jakiegoś znacząco różnego miejsca. (...) Wymaga się intensywnej, „głębokiej” wzajemnej relacji, czegoś, co w sposób kanoniczny zapewnia praktyka przestrzenna długotrwałego, nawet jeśli tylko czasowego, zamieszkiwania w danej społeczności. Badania terenowe mogą się również wiązać z powtarzającymi się krótkimi wizytami $(. . .)^{4}$.

To klasyczne ujęcie terenu uległo swoistej modyfikacji, fizyczne opuszczenie domu nie musi się już wiązać z wyjazdem do innej kultury. Obecnie inność i teren zauważane są również wokół nas, w naszym życiu codziennym: w pracy, na podwórku itp. Nie musi być również związany z ludźmi odległymi przestrzennie czy kulturowo (anthropology at home ${ }^{5}$, etnografia wielomiejscowa ${ }^{6}$ ). Niezależnie jednak od dystansu dzielącego badacza od badanego, teren związany z ich wzajemną interakcją, jest terenem rzeczywistym, charakteryzującym pracę antropologa. W jego skład wchodzi nie tylko sama przestrzeń społeczno-kulturowa, wydarzenia i sytuacje rozmowy, badani, lecz również, o czym dobrze wiemy po zwrocie interpre-

${ }^{2}$ K. Kaniowska, Stare problemy nowej antropologii, „Przegląd Socjologiczny” 2004, nr 1, s. 51-70.

${ }^{3}$ Opisy różnych sposobów ujmowania terenu można znaleźć w książce Teren $w$ antropologii. Praktyka badawcza we współczesnej antropologii kulturowej, pod. red. T. Bulińskiego, M. Kairskiego, Wydawnictwo Naukowe UAM, Poznań 2011.

${ }^{4}$ J. Clifford, Praktyki przestrzenne: badania terenowe, podróże i praktyki dyscyplinujące $w$ antropologii, [w:] Badanie kultury. Elementy teorii antropologicznej. Kontynuacje, pod. red. M. Kempengo, E. Nowickiej, Wydawnictwo Naukowe PWN, Warszawa 2004, s. 145.

${ }^{5}$ W. Kuligowski, Defamiliaryzacja i inne praktyki antropologii bliskości, [w:] Tubylcy własnego świata. W stronę antropologii bliskości, pod. red. tegoż, Polskie Towarzystwo Ludoznawcze, Poznań 2011, s. 7-15.

${ }^{6}$ G. E. Marcus, Użyteczność kategorii uczestnictwa w zmieniających się kontekstach badań terenowych [w:] Clifford Geertz - Lokalna lektura, pod. red. D. Wolskiej, M. Brockiego, Wydawnictwo Uniwersytetu Jagiellońskiego, Kraków 2003, s. 155-181. 
tacyjnym, sama osoba badacza ${ }^{7}$. Taka perspektywa patrzenia na zagadnienia, które zajmują antropologów wymaga również specyficznych technik, metod, narzędzi pomagających uchwycić i wytworzyć wiedzę antropologa i wiedzę antropologiczną. W samym procesie badawczym, podczas pobytu w terenie często trudno przeprowadzić wyraźną granicę pomiędzy poszczególnymi taktykami badawczymi oraz pomiędzy tym, co jest częścią „profesjonalizmu" zawodowego a tym, co stanowi element naszego, „ludzkiego" istnienia w świecie. Warto podkreślić tutaj bardzo istotną cechę przebywania w terenie i jego doświadczania, a mianowicie zintensyfikowanie owej sytuacji w porównaniu z „nie-byciem” w terenie. Poczucie i chęć interpretacji jak największej ilości bodźców docierających do badacza, owo nastawienie na otwarcie i wchłonięcie przez teren, gdzie nie wiadomo, co i kiedy zaważy o kształcie naszej zdobytej wiedzy wymaga pewnych specyficznych umiejętności, wrażliwości i skupienia, które wspierane są przez odpowiednie narzędzia, techniki badawcze oparte o konkretnie wybrane metody, dostosowane do swoistości konkretnego terenu.

W procesie edukacji etnologa momentem, w którym student ma możliwość nabycia tych umiejętności oraz nauczenia się posługiwania konkretnymi narzędziami i technikami badawczymi są ćwiczenia terenowe. Skoncentrujemy się tutaj na przykładzie łódzkiej etnologii, gdzie pierwsze spotkanie studentów z terenem następuje już w trakcie pierwszego roku studiów, mianowicie w marcu w trakcie 10-dniowych ćwiczeń terenowych. Ćwiczenia te są jedną z form dydaktycznych stosowanych w procesie kształcenia etnologów. Wiosenne ćwiczenia terenowe ${ }^{8}$, bo o takich tu mowa, są nieodłączną częścią wykładu z Metodyki etnograficznych badań terenowych. Na wykładzie studenci zapoznają się z metodami, technikami, narzędziami, a szerzej mówiąc sposobami pracy w terenie. Wyjazd w teren ma ich nauczyć praktycznego posługiwania się zdobytą wiedzą. Ten cel jest zgodny z tym, co Franciszek Bereźnicki uznaje za zadanie ćwiczeń, czyli: „wyrobienie umiejętności świadomego korzystania z wiedzy naukowej w różnych operacjach umysłowych i w praktyce” ${ }^{\prime \prime}$, oraz „przygotowanie do pracy zawo-

\footnotetext{
7 M. Rakoczy, Wokół zwrotu interpretetywnego, „Przegląd Humanistyczny” 2008, nr 5, s. 29-42.

${ }^{8}$ Studenci łódzkiej etnologii uczestniczą w różnego rodzaju badaniach terenowych podczas trwania swojej nauki - jednak ćwiczenia, o których tu mowa są wyjątkowe przez ich charakter dydaktyczny, wprowadzający w warsztat badawczy.

${ }^{9}$ F. Bereźnicki, Organizacyjne formy kształcenia w szkole wyższej, [w:] Wprowadzenie do pedagogiki szkoły wyższej, pod. red. K. W. Jaskota, Oficyna, Szczecin 2006, s. 194.
} 
dowej poprzez przyswajanie umiejętności zawodowych"10. Ćwiczenia terenowe, będące pracą praktyczną charakteryzują się realnym rodzajem pracy, potrzebą rozwiązywania faktycznie zaistniałych problemów, a nie wirtualnie wyabstrahowanych sytuacji stworzonych przez prowadzącego zajęcia na potrzeby ćwiczeń. W tym aspekcie przypominają trochę ćwiczenia kliniczne, które są charakterystyczną formą zajęć na uczelniach medycznych.

Przeprowadzanie rozmów z drugim człowiekiem, dokonywanie obserwacji jego życia, wprowadza do formy pracy dydaktycznej, jaką są ćwiczenia terenowe, czynnik ludzki, niezależny ani od prowadzącego, ani od studenta. Człowiek, będący badanym, partnerem interakcji nie musi się podporządkowywać procedurom, narzędziom, metodom, może reagować w dowolny dla siebie sposób, który tworzy często nieoczekiwane i trudne dla studentów do przezwyciężenia problemy i sytuacje. Dlatego etnologiczne badania terenowe to nie tylko umiejętność stosowania określonych procedur. To przede wszystkim umiejętność obserwacji, empatii, wyczucia, autoobserwacji itp. To nie tylko zdolność do zastosowania wyuczonych technik, to też umiejętność odnalezienia się w różnych sytuacjach, na jakie natrafiamy w terenie, a których nie jesteśmy w stanie do końca przewidzieć, ponieważ każdy teren jest inny i stawia przed badaczem różne wymagania. To z kolei przekłada się na sposoby nauczania pracy terenowej, które bliższe są praktykom studenckim, których celem jest: „uzupełnianie wiedzy, nabywanej na różnych zajęciach dydaktycznych, określonym zasobem wiedzy i umiejętności praktycznych, zdobywanej bezpośrednio podczas wykonywania zadań praktycznych w zakładach pracy"11, niż ćwiczeniom akademickim.

Próżno, więc szukać opisu ćwiczeń terenowych w podręcznikach do dydaktyki w szkole wyższej. Ich specyfika i niszowość sprawiają, że właściwie nie przystają do innych form pracy ćwiczeniowej stosowanej w szkołach wyższych. Wynika to głównie ze specyfiki poznania antropologicznego, które za sprawą dokonań antropologii refleksyjnej, gdzie istotną częścią wytwarzanej w terenie wiedzy antropologicznej jest samoświadomość badacza dotycząca jego uwikłania w proces doświadczania, poznania i w końcu interpretowania rzeczywistości, skutkuje zwiększającą się rolą tych części pracy, w których ukazuje się osoba badacza, jako taka. Pomocne w uzyskiwaniu tego rodzaju „danych" stają się takie techniki jak field notes,

\footnotetext{
10 Tamże, s. 195.

11 Tamże, s. 209.
} 
head notes czy też w końcu dzienniki badawcze. Za pierwowzór tych ostatnich przyjmuje się dzienniki Bronisława Malinowskiego, które to pokazały antropologom, że badacz nie jest w stanie uwolnić się od siebie samego, swoich przekonań i odczuć w czasie pobytu w terenie, i że ta część doświadczenia terenowego badacza jest równie ważna jak pozostałe. Sam Malinowski dostrzega owo uwikłanie badacza w sytuację, o czym we wstępie do polskiego wydania jego dzienników pisze Grażyna Kubica następująco:

Zgodnie z tym, co pisał Malinowski o swoich dziennikach, zawierają one przede wszystkim autoanalizę. Jest ona mniej lub bardziej ogólna, dotyczy różnych kwestii, ale chodzi w niej o jedno: uchwycić stan obiektu, który poddaje się eksperymentowi. Opisać go. Zdać sobie sprawę ze stanu rzeczy ${ }^{12}$.

Malinowski traktował dziennik nie, jako narzędzie badawcze, lecz jako formę samo dyscyplinującego ćwiczenia, zadania do wykonania. Jednakże z tego powodu, iż pisał swój dziennik w trakcie intensywnych badań terenowych przyjęto traktować jego prywatne zapiski, jako źródło wiedzy antropologicznej o dziennikach badawczych. We współczesnej antropologii konieczne jest dostrzeżenie i przeformułowanie roli badacza w procesie badawczym, jako tego, który współtworzy i współdoświadcza teren wraz ze swoimi badanymi. Trzeba jednak zastrzec, że dzienniki Malinowskiego miały charakter intymny, prywatny i jego intencją nie było ich upublicznianie, ani tym bardziej traktowanie, jako jednego ze sposobów prezentacji wiedzy zdobytej w terenie. Dzienniki pisane przez antropologów możemy, na potrzeby naszej analizy, podzielić na osobiste, intymne oraz te o charakterze badawczym. Oczywiście jest to arbitralny podział, który często w rzeczywistości nie jest ostry, ponieważ nie można traktować zapisków zawartych w obu tych dziennikach rozłącznie. Te dwa sposoby spisywania przeżyć przeplatają się, co w efekcie może skutkować prowadzeniem dziennika terenowego zawierającego spore fragmenty przynależne narracji osobistej, wręcz intymnej. Dziennik terenowy to przestrzeń gdzie antropolog dokonuje pierwszych, wstępnych interpretacji, gdzie utrwala swoje przeżycia i odczucia, nagromadzone podczas pobytu w terenie. Staje się on miejscem na myśli, na które nie ma miejsca gdzie indziej. Myśli, które mogłyby wydawać się na pierwszy rzut oka nieistotne, czy wręcz zaciem-

${ }^{12}$ G. Kubica, Wstęp, [w:] B. Malinowski, Dziennik w ścisłym znaczeniu tego wyrazu, Wydawnictwo Literackie, Kraków 2002, s. 20. 
niać obraz tworzony w trakcie pozyskiwania materiału. Pozwala on także na prezentację nastawienia, opisów sytuacji, które znajdują się na pograniczu usystematyzowanych i zdyscyplinowanych praktyk antropologicznych, jak również ponowne przedstawienie sytuacji, które zapadły w pamięć. To tutaj jest miejsce na zapisywanie wrażeń estetycznych, emocjonalnych, nastawienia psychicznego ujawniających się wraz z doświadczaniem przez badacza terenu i badanego. W przekonaniu Kaniowskiej dzięki zmianie paradygmatu nastąpiła bardzo ogromna zmiana dotycząca sposobu pojmowania empirycznego doświadczenia, co z kolei wpłynęło na narracje i interpretacje antropologiczne. „W rezultacie to, co w antropologii uznawane było za pozalogiczne w poznaniu, zyskało status nowego i - co ważniejsze - koniecznego elementu poznania fundującego naszą wiedzę"13. Tym sposobem własne doświadczenia badacza, zaangażowanie, intuicje, odczucia, przeczucia i wszelkie aspekty emocjonalne stały się pełnoprawnym elementem poznania. Chociaż nie należą do porządku logicznego ich wartość dla nauki jest niepodważalna. 0 potrzebie spisywania tego różnego rodzaju danych i narracji w trakcie badań terenowych możemy przeczytać w Analizie układów społecznych:

Oprócz informacji na temat układu, ludzi, wydarzeń, zaobserwowanych interakcji i pomysłów analitycznych, w notatkach powinno znaleźć się miejsce na zapisywanie odczuć i wrażeń badacza - jego osobistych opinii na temat ludzi, których bada, reakcji emocjonalnych towarzyszących badaniu oraz uczuć dotyczących samego układu (...) badacz może czuć się zniechęcony, radosny, odrzucony, kochany. Etnograf powinien zapisywać każdy aspekt emocjonalnego zaangażowania w układ, aby zapewnić sobie pewien stopień dystansu ${ }^{14}$.

Dziennik terenowy daje możliwość pogłębienia refleksji, rozciągnięcia, czy wręcz zatrzymania doświadczania w czasie, co w efekcie pozwala na wytchnienie, nabranie niezbędnego dystansu. Ta forma komfortu psychicznego wpisuje się w istotny aspekt procesu badawczego a mianowicie w strategie balansowania między zanurzeniem się w terenie a dystansowaniem się względem niego, jako nieustającej gry napięcia wytwarzającej to, co stanowi

${ }^{13}$ K. Kaniowska, Heurystyczna wartość wiedzy antropologicznej [w:] Zanikające granice. Antropologizacja nauki i jej dyskursów, pod. red. A. Pomiecińskiego, S. Sikory, Biblioteka Telgte, Poznań 2009, s. 33.

${ }_{14}$ J. Lofland, D. A. Snow, L. Anderson, L. H. Lofland, Analiza układów społecznych. Przewodnik metodologiczny po badaniach jakościowych, Wydawnictwo naukowe Scholar, Warszawa 2009, s. 168. 
wiedzę terenową. Zapiski te pozwalają przekształcić wielość znaczeń, informacji oraz spostrzeżeń docierających do badacza w terenie w niezbędną formę narracji, która to dzięki utrwaleniu może podlegać analizie i interpretacji ${ }^{15}$. Im także poddawane są emocje i odczucia, które dzięki utrwaleniu w postaci zapisków mogą zostać poddane transformacji w część wiedzy antropologicznej, która nie ma już charakteru intymnego, osobistego, prywatnego ${ }^{16}$.

Dziennik terenowy ma również wymiar samo dyscyplinujący, pomaga usystematyzować pracę oraz przypomina o nieustającym trwaniu procesu badawczego, narzucając tym samym rygor pracy. Systematyczne zapisywanie pozwala, choć po części zniwelować mankamenty wynikające z niedoskonałości naszej pamięci ${ }^{17}$.

Wskazane wyżej zalety prowadzenia dziennika terenowego skłoniły nas do włączenia tej praktyki w proces dydaktyczny i zaproponowania studentom prowadzenia zapisków przed, w trakcie i po ćwiczeniach terenowych. W naszej pracy ze studentami z założenia miałyśmy, więc do czynienia z dziennikami terenowymi, nie osobistymi, lecz specyficznego rodzaju. Wynikało to ze świadomości studentów, że dzienniki te stanowią część ich pracy podlegającej naszej ocenie.

Drugim powodem, który sprawił, że postanowiłyśmy wykorzystać w pracy dzienniki była świadomość specyfiki uczenia się ludzi dorosłych. Należy pamiętać, że studenci rozpoczynający swoją przygodę z uczelnią wyższą, są już ludźmi dorosłymi, potrafiącymi autonomicznie myśleć i decydować oraz mają wykształcony system wartości i sposób patrzenia na świat. W efekcie najlepszym sposobem ich kształcenia jest empiria, czyli doświadczenie $^{18}$. W świetle wyżej przytoczonych słów, oczywistym jest, iż ćwiczenia terenowe są idealną okazją do zdobycia doświadczenia etno-

${ }^{15}$ W. Kędzierzawski, Codzienność jako kategoria antropologiczna perspektywie historii kultury, Uniwersytet Opolski, Opole 2009.

${ }^{16}$ M. Hammersley, P. Atkinson, Metody badań terenowych, Wydawnictwo Zysk i S-ka, Poznań 2000, s. 198.

17 Korzyści płynące z prowadzenia dziennika badacza są nie tylko i wyłącznie związane z aspektami metodologicznymi związanymi z nurtami takimi jak antropologia refleksyjna czy autoetnografia. O roli wspomagającej proces pracy badawczej, samo dyscyplinującej i systematyzującej możemy przeczytać między innymi u D. Silvermana w pracy Prowadzenie badań jakościowych, Wydawnictwo Naukowe PWN, Warszawa 2008, s. 300.

${ }^{18}$ A. Baran, Komunikacja dydaktyczna, [w:] Wykładowca doskonały. Podręcznik nauczyciela akademickiego, pod. red. A. Rozmusa, Wolters Kluwer Polska Sp. z o.o., Warszawa 2010, s. 15-47. 
graficznego, do nauki poprzez doświadczenie. Należy jednakże pamiętać, że w procesie uczenia się, samo doświadczenie, bez refleksji nad nim, jest właściwie bezwartościowe. Z tego powodu postanowiłyśmy skorzystać z dziennika badacza, jako środka dydaktycznego w procesie nauczania-uczenia się, mającego na celu pomóc studentom zrozumieć proces, jakim jest doświadczenie etnograficzne.

Jak podaje Czesław Kupisiewicz:

Środki dydaktyczne są to przedmioty, które, dostarczając uczniom określonych bodźców sensorycznych oddziałujących na ich wzrok, słuch, dotyk itd., ułatwiają im bezpośrednie i pośrednie poznawanie rzeczywistości. Słowo „przedmiot” użyte w powyższej definicji, odnosi się zarówno do przedmiotów oryginalnych, jak i do ich zastępników modelowych, obrazowych, słownych lub symbolicznych ${ }^{19}$.

Dziennik terenowy jest, zatem środkiem dydaktycznym szczególnego rodzaju, który poprzez słowa, zapisane własnoręcznie przez studenta i późniejszy namysł nad nimi wraz z prowadzącym ćwiczenia, a czasem z całą grupą, pomaga zrozumieć, w jaki sposób badacz poznaje rzeczywistość i jaką rolę w tym poznawaniu odgrywa. Korzystanie z pomocy dziennika jest możliwe dzięki zastosowaniu przez nas w trakcie ćwiczeń terenowych modelu kształcenia akademickiego zwanego: humanistycznym ${ }^{20}$, społecznym ${ }^{21}$, czy uczeniu się we współpracy ${ }^{22}$. Niezależnie od nazwy, którą przyjmiemy model ten pomaga uczyć się dzięki społecznym kontaktom, dzięki współpracy w grupie. Jest on również nastawiony na indywidualizujące podejście do studenta i pomaganie w rozwoju jego możliwości. To z kolei wiąże się z koniecznością wytworzenia nici zaufania między studentami a prowadzącymi ćwiczenia, jest szczególnie istotne i ważkie w przypadku pracy za pomocą dziennika terenowego. Mimo wyraźnego podkreślenia jego otwartej formy i wiedzy studentów o tym, że będziemy go czytały miałyśmy świadomość, że studenci mogli nieświadomie pokazać się w nie

${ }^{19}$ Cz. Kupisiewicz, Podstawy dydaktyki ogólnej, Państwowe Wydawnictwo Naukowe, Warszawa 1978, s. 242.

${ }^{20}$ S. Palka, Aktualne tendencje $w$ dydaktyce akademickiej, [w:] W poszukiwaniu modelu dydaktyki akademickiej, pod. red. D. Skulicz, Wydawnictwo Uniwersytetu Jagiellońskiego, Kraków 2004, s. 31-36.

${ }^{21}$ K. Polak, Modele nauczania i możliwości ich wykorzystania w dydaktyce akademickiej, [w:] W poszukiwaniu modelu dydaktyki akademickiej, pod. red. D. Skulicz, Wydawnictwo Uniwersytetu Jagiellońskiego, Kraków 2004, s. 91-96.

${ }^{22}$ E. Piotrowski, O osobliwości kształcenia w szkole wyższej, [w:] Wprowadzenie do pedagogiki szkoły wyższej, pod. red. K. W. Jaskota, Oficyna, Szczecin 2006, s. 175-185. 
zawsze korzystny dla siebie sposób. Tutaj potrzebna nam stała się owa wrażliwość antropologiczna, która pozwalała nam na owocną współpracę i relację z „badanymi - studentami” oraz na późniejszą interpretację owych dzienników.

\section{Co dziennik nam powie?}

Podczas dwóch lat wiosennych badań terenowych, gdy zaproponowałyśmy swoim grupom pracę nad dziennikami terenowymi udało się nam zgromadzić wiele opowieści, narracji dotyczących doświadczeń młodych badaczy podczas ich pierwszego kontaktu z terenem. Charakteryzująca je różnorodność treści związana jest oczywiście z różnymi typami osobowości oraz temperamentów, charakterów naszych studentów. Ponieważ dzienniki zawierały różnorakie treści, postanowiłyśmy zgodnie z naszą etyką badawczą oraz dydaktyczną zmniejszyć do minimum możliwość rozpoznania autorów oraz osób występujących w cytowanych przez nas fragmentach, - dlatego też wszelkie nazwiska i imiona zostały ukryte pod pseudonimami. W tym miejscu chciałybyśmy przyjrzeć się bliżej zgromadzonym materiałom dzieląc je na wybrane przez nas obszary, zagadnienia, mając na celu ich analizę i interpretację.

Rozpoczniemy po części oddając się chronologicznej logice, zastrzegając jednak, że nie w każdym przypadku opisywane i poddawane oglądowi fragmenty pojawiały się w tych samych momentach pobytu w terenie. $\mathrm{Na}$ samym początku omówimy nastawienie, emocje oraz postawy, które towarzyszyły młodym badaczom przed wejściem w teren oraz gdy mieli do czynienia z pierwszymi próbami działania, jako antropologa podczas badań. Ich wyjątkowy, niejasny stan oraz uczucia im towarzyszące mogą zobrazować słowa jednej ze studentek: „Pierwszy wyjazd, pierwsze ćwiczenia terenowe i moje wrażenia wypełniają emocje, które przechodzą ze skrajności w skrajność"23. Wielu z pośród studentów pisało o podekscytowaniu wynikającym z nowego wyzwania, przed którym mieli stanąć. Z jednej strony nie mogli się doczekać tego, co przyniesie im ten wyjazd, czego doświadczą, z drugiej strony paraliżował ich strach i niepewność tego, co może ich spotkać. Potęgowane było to niejednokrotnie opowieściami, których mieli okazję wysłuchać od wykładowców, opiekunów grup oraz starszych kolegów. Otrzymywanie skrajnie różnych informacji, poczynając od tych

\footnotetext{
${ }^{23}$ Dziennik: R16, dzień 1.
} 
mówiących o świetnej zabawie i niezapomnianym przeżyciu po te tworzące swoiste legendy etnologiczne, o ciężkiej pracy i niebezpieczeństwach czających się w terenie (takich jak osławione już ataki psów) wpływało jeszcze bardziej na poczucie niepewności względem tego, co ich spotka. Studenci postrzegali wyjazd, jako swoiste wyzwanie, sprawdzenie w praktyce tego, o czym słuchali od początku swojej przygody z etnologią. Skutkowało to pojawieniem się również refleksji na temat własnych zdolności, predyspozycji, wiedzy potrzebnej w terenie oraz umiejętności radzenia sobie z trudnościami w terenie. Doskonale obrazuje to poniższy fragment:

\footnotetext{
Wywiady... to dopiero będzie... niby wiem wszystko a jednak chyba nie wiem nic. (...) Co jeśli się nie sprawdzę? Będę siedziała tam miesiąc i poprawiała wywiady. (...) Jedyne, co mi poprawia humor w tym temacie to to, że przecież wywiady to tylko będzie rozmowa z obcym człowiekiem. A w rozmowach zawsze byłam całkiem dobra. Tylko to słowo „wywiad” tak straszy no i „badania terenowe”. (...) Kolejną rzeczą jest to, że nigdy nie wiadomo, na jakich ludzi się trafi a jeszcze włazi się im do domu... Może będą niemili, może pijani. Bóg jeden wie, co może się wydarzyć. Oczywiście wyrzucania, odmów też się obawiałam, na tym etapie takie rzeczy mogą podcinać skrzydła i to tak poważnie. Ale optymistyczna strona mojej osobowości każe mi teraz napisać, że jak nie ten dom to następny ${ }^{24}$.
}

Przedstawiona $\mathrm{w}$ tej wypowiedzi obawa wynikała $\mathrm{z}$ poczucia presji profesjonalizmu, powagi zadania, które zostało postawione przed uczestnikami ćwiczeń. Pytania, myśli, które dręczyły studentów dotyczyły tego, czy będą potrafili przełamać nieśmiałość, podejść do obcego człowieka i rozpocząć rozmowę, czy będą potrafili odpowiednio ją poprowadzić, zadać trafne i sensowne pytania. Również pierwsze doświadczenia, pierwsze „wyjście w teren” w większości przypadków potęgowało ów strach i niepewność. Liczne odmowy, problemy z przełamaniem bariery wstydu, zmęczenie i znużenie było dla studentów zderzeniem z trudnościami, z jakimi antropolog przychodzi się mierzyć i powoli zaczynali zdawać sobie sprawę, że czeka ich zmaganie się nie tylko z merytorycznymi problemami wynikającymi z rozmów z innymi ludźmi, ale również ze swoimi własnymi ograniczeniami.

Jak już wcześniej wspomniałyśmy badania terenowe są dla etnologów wyróżnikiem ich dyscypliny. Odbycie praktyki terenowej świadczy o profesjonalizmie, o byciu prawdziwym antropologiem. Zaświadczają o tym słowa Paula Rabionowa:

${ }^{24}$ Dziennik: I, 02.03.2012. 
Na wydziale studiów magisterskich z antropologii na Uniwersytecie w Chicago, świat składał się z dwóch kategorii ludzi: tych, którzy prowadzili badania terenowe, i tych, którzy tego nie zrobili. Ci ostatni nie byli „prawdziwymi” antropologami niezależnie od tego, co wiedzieli na temat antropologicznych kwestii. Na przykład profesor Mircea Eliade był człowiekiem wielkiej erudycji w dziedzinie religii porównawczej, budził szacunek ze względu na swą encyklopedyczną wiedzę, niemniej stale podkreślano, że nie jest on antropologiem: jego intuicja nie została zmieniona alchemią badań terenowych ${ }^{25}$.

W tej wypowiedzi Paul Rabinow przedstawia nam dość skrajne stanowisko, jakie funkcjonowało w antropologii w Stanach Zjednoczonych w ubiegłym stuleciu. Myśliciele pokroju Mircei Eliadego za sprawą jednego faktu - nie prowadzenia badań terenowych - nie byli uważani za antropologów. Czytając dalej dowiadujemy się, że zarzuty studentów wobec mistrzów antropologii, u których widzieli rażące braki przygotowania teoretycznego i namysłu nad tymi kwestiami były przez wykładowców ignorowane, ponieważ „ci autorzy byli wielkimi badaczami terenowymi”26 - jakby to było usprawiedliwieniem. $\mathrm{W}$ takim rozumieniu bycie antropologiem oznaczało bycie praktykiem, terenowcem, a bycie terenowcem dawało przyzwolenie na określanie się mianem antropologa. Przenosząc się na grunt polskiej etnologii można odnieść wrażenie, że tutaj przyzwolenie o mówieniu o terenie jest dane tym, którzy w jakiś sposób go doświadczyli, a nie tylko o nim teoretyzowali. Wskazują na to słowa Sławomira Sikory:

$\mathrm{Ba}$, od kiedy usłyszałem referat na temat wagi badań terenowych, (jako centrum dyscypliny), wygłaszany przez osobę, która nigdy (przynajmniej poważniejszych) nie prowadziła, zrozumiałem (nie po raz pierwszy zresztą), że swoista precesja symulacrów dotknęła także antropologię ${ }^{27}$.

Okazuje się, że zdziwienie wywołują rozważania o terenie podnoszone przez teoretyków. W kontekście powyższej wypowiedzi pojawia się pytanie, o jakość badań terenowych. Wygląda na to, że można je podzielić na bardziej i mniej poważne. Tego, jakie są kryteria klasyfikacji poszczególnych badań Sikora nam nie zdradza. Istotniejszy jest jednak fakt, że teoretycy nie prowa-

${ }^{25}$ P. Rabinow, Refleksje na temat badań terenowych w Maroku, Wydawnictwo Marek Derewecki, Kęty 2010, s. 32 .

${ }^{26}$ Tamże, s. 33.

27 S.Sikora, Odwrócone spojrzenie albo antropologizacja antropologii, [w:] Zanikające granice. Antropologizacja nauki i jej dyskursów, pod. red. A. Pomiecińskiego, S. Sikory, Biblioteka Telgte, Poznań 2009, s. 73. 
dzą badań terenowych, przynajmniej poważniejszych, czyli wartościowszych, co stawia ich w innym rzędzie antropologii niż terenowców, jednak nie sytuuje poza granicami dyscypliny, na co wskazywałyby słowa Rabinowa. Toczone przez lata dyskusje o terenie i jego znaczeniu dla dyscypliny nie pozwalają antropologom przechodzić obojętnie nad tą kwestią. Określenie własnego stanowiska w tej sprawie przez pracowników naukowo-dydaktycznych ma bezpośrednie przełożenie na opinie studentów, którzy już od pierwszych zajęć się z nimi zapoznają. Także lektury, które czytają, jak chociażby książki Bronisława Malinowskiego, Claude’a Levi-Straussa, Kazimiery Zawistowicz-Adamskiej przekonują ich o doniosłości pracy terenowej. Częstotliwość mówienia o terenie na zajęciach, oprócz konieczności wynikających z programu studiów jest też związana z tym, że na pierwszym roku, już od pierwszego semestru mają zajęcia z wykładowcami, z którymi następnie jadą w teren. Również, co zostało już wcześniej powiedziane, starsi studenci podsycają swymi opowieściami zainteresowanie pierwszoroczniaków terenem. To zintensyfikowane traktowanie terenu wytworzyło wokół ćwiczeń terenowych atmosferę tajemnicy i niezwykłości. Zaczęły one być traktowane niczym „obrzęd przejścia”. Chociaż symbolicznego obrzędu przejścia doznali w trakcie fuksówki, kiedy zostali przyjęci do studenckiej braci etnologów. Jednak stanie się prawdziwym etnologiem jest przez nich kojarzone z koniecznością odbycia ćwiczeń terenowych. Przekonanie, że dzięki tym zajęciom staną się profesjonalistami budzi jednocześnie strach i podekscytowanie na perspektywę czekającego ich wyzwania.

Początkowo pojawiające się $\mathrm{w}$ wyniku zderzenia $\mathrm{z}$ rzeczywistością pracy antropologa problemy, zniechęcenie i rozczarowanie, potrafiły odejść w cień i oddać pola kompletnie skrajnej i odmiennej postawie i nastawieniu. Warto tu zaznaczyć, że emocje, które towarzyszyły studentom zmieniały się diametralnie oraz były bardzo intensywne - wyciągnięcie ich z codzienności i umieszczenie w nowym, nieznanym kontekście potęgowało to, co przyszło im doświadczać. Zmiana nastawienia związana była najczęściej ze spotkaniem, doświadczeniem rozmowy i wrażeniem natrafienia w końcu na „dobrego” rozmówcę. Taka osoba cechowała się otwartością, chęcią do rozmowy, opowiadała ciekawie i interesująco, była zaangażowana, co skutkowało tym, że młodzi adepci antropologii odczuwali satysfakcję i dostrzegali sens swoich działań. Niejednokrotnie spotkanie tej 
osoby, czy osób można by było nazwać momentem przełomowym w trakcie pobytu w terenie - to uczucie jest znane powszechnie antropologom, kiedy pewne doświadczenie podczas badań, otwiera im pole do zanurzenia się w daną społeczność, problem, zagadnienie. Przykład taki możemy odnaleźć u Clifforda Geertza, który zamieszkał wraz ze swą żoną w wiosce, aby wiedzę o jej rzeczywistości uzyskać od wewnątrz. Ze strony społeczności nie spotkali się oni z zainteresowaniem swoją pracą. Problemem nie było to, że byli postrzegani, jako wrogowie, lecz o to, że w ogóle nie byli zauważani. Czuli się przezroczyści, jakby patrzono poprzez nich. Momentem przełomowym w ich działaniach stał się udział w nielegalnej walce kogutów, a właściwie ucieczka, wraz z innymi obserwującymi przed policją, która rozpędziła nieprawne zgromadzenie. Od tej chwili wszystkie drzwi były przed nimi otwarte. Ludzie nie tylko chcieli z nimi rozmawiać, ale nawet sam naczelnik wioski bronił ich, kiedy policja wypytywała o uczestnictwo antropologów w nielegalnym zgromadzeniu. Momenty przełomowe w praktyce terenowej pojawiają się również w opisach innych badaczy. Aby pozostać w tradycyjnej scenerii badań, przytoczę tu przykład badań Kazimiery Zawistowicz-Adamskiej. Żyjąc przez długi czas wśród obcych jej dotychczas ludzi udało jej się zyskać ich zaufanie, przy czym nie było to tylko subiektywne odczucie badaczki. Zaborowianie dali temu wyraz, kiedy w kościele w trakcie pogrzebu wręczyli jej świecę, jaką otrzymywali bliscy zmarłego. W ten sposób chcieli ją uhonorować i dać odczuć, że przyjmują do swojej grupy. Można to rozpatrywać, jako swego rodzaju wyróżnienie. W tej sytuacji, która wyrażała więzi łączące mieszkańców Zaborowa, badaczka została uznana za członka społeczności. Jak sama przyznaje od tego momentu czuła się pewniej wśród Zaborowian. To symboliczne, ale jakże istotne i realnie poświadczone włączenie do grupy spowodowało swobodniejszy kontakt z badanymi ludźmi. Łatwiej jej się rozmawiało, porozumienie przychodziło swobodniej a ludzie sami z siebie też życzliwiej się do niej odnosili i chętniej rozmawiali ${ }^{28}$. Zestawione tu dwie sytuacje: ucieczka przed policją na Bali i uczestnictwo w pogrzebie w Zaborowie były okazją zamanifestowania solidarności badacza z badaną grupą. Jak sam Geertz zauważył, w jego przypadku wydarzenie to było całkowicie przypadkowe i niezaplanowane.

${ }^{28}$ K. Zawistowicz-Adamska, Społeczność wiejska. Doświadczenia i rozważania z badań terenowych w Zaborowie, Polskie Instytut Służby Społecznej, Łódź 1948. 
Z kolei u Zawistowicz-Adamskiej wynikało ono z uprzedniego zżycia się badacza z grupą. Chociaż w obydwu przypadkach od tego momentu etnografowie poczuli się częścią badanej grupy, a rozmowy stały się swobodniejsze, to ich sytuacja wyjściowa, sprzed momentu przełomowego, zdecydowanie się różniła ${ }^{29}$. Zawistowicz-Adamska nie miała takich trudności z pozyskaniem rozmówców i zdobyciem danych jak Geertz. Zażyłość w jej przypadku pojawiła się zdecydowanie wcześniej, a wręczenie świecy było symbolicznym przyjęciem do wspólnoty. W sytuacji Geertza moment przełomowy sprawił, że w ogóle pojawiła się możliwość uzyskania danych.

Studenci $w$ tych momentach przełomowych albo odczuwali zaciekawienie wynikające $\mathrm{z}$ kontaktu $\mathrm{z}$ odmiennym często dla nich światem, bądź też odnajdywali w tej odmiennej sytuacji elementy ich życia, codzienności. Obcowanie z innymi, którzy chcą podzielić się swoim czasem oraz historią wpływało na zmianę, pobudzenie ciekawości. Bardzo często rozmówcami były osoby starsze cieszące się z możliwości kontaktu. Gdy studenci dostrzegali, że ich zadanie to także rozmowa, która może być ważna dla drugiej strony, wzbudza emocje i zaangażowanie, doceniali wartość swoich działań i ich wagę. O takiej obopólnej potrzebie kontaktu może świadczyć poniższy fragment:

Po przejściu kolejnych kilometrów trafiliśmy na pierwszą rozmówczynię. Byliśmy już tak zrezygnowani i przybici, że miła staruszka zupełnie nas zaskoczyła. Sprawiała wrażenie, że czeka na kogokolwiek, kto by ją odwiedził. Ugościła nas herbatą i ciasteczkami ${ }^{30}$.

Czasem historie usłyszane wywoływały silne emocje nie tylko u rozmówców, ale również u młodych badaczy:

Ciarki przechodziły mi po całym ciele, a łzy coraz bardziej zaczęły wypełniać moje oczy. Pierwszy raz miałam okazję porozmawiać z obcą osobą, która potrafiła się zwierzyć ze swoim przeżyć prywatnych. Rozmowa z nią przebiegała mi tak szybko, że aż nie chciało się wychodzić. (...) Rozmowa z Panią M. była cudowna. Wychodząc od niej z domu czułam w sobie jeszcze emocje ${ }^{31}$.

${ }^{29}$ Należy również pamiętać, że K. Zawistowicz-Adamska badała grupę należącą do jej własnego kręgu kulturowego oraz posługiwała się swoim ojczystym językiem, natomiast C. Geertz badał grupę obcą mu kulturowo, gdzie jedną z trudności było przezwyciężenie bariery językowej.

30 Dziennik: H, 10.03.2012.

${ }^{31}$ Dziennik: R10, dzień 5. 
Jako istotną wartością dla owocnego spotkania studenci wskazywali również atmosferę, na którą składały się serdeczność, ciepło, gościna i otwartość, która pokazywała im, że ludzie mogą reagować pozytywnie na ich obecność. W tych momentach również pojawiała się refleksja nad możliwością odwdzięczenia się za poświęcony czas i wiele więcej. Jeden z uczestników ćwiczeń opowiada o takim spotkaniu i refleksji po nim tak:

Jakąż radość i powrót fali entuzjazmu wywołał szczek skoble w drzwiach i poczciwa staruszka, która nie czekając nawet na nasze szczegółowe wyjaśnienia, zaprosiła nas do środka, jak gdyby czekała na nas. Rozmowa z nią i siedzenie w jej izbie były istnym spełnieniem naiwnego marzenia o podróży w czasie. (...) w sumie wywiad nie był zbyt szczegółowy i spektakularny, ale może to i lepiej, że pierwszy kontakt z człowiekiem odbył się w takiej atmosferze. (...) Pokrzepieni domowym ciepłem oraz herbatą z ciastkami, ruszyliśmy dalej ku os. Sikory. Po wyjściu od pani M. z niezrozumiałych przyczyn moje sumienie dało znać, że coś jest nie tak. Po chwili zrozumiałem... rozmowa, która przed chwilą przeprowadziłem, była nieuczciwa. Więcej rzeczy wyciągnąłem z rozmówcy, niż sam dałem. (...) W tej chwili postanowiłem, że następnym razem postaram się, aby rozmówca też coś z tego miał, że mnie wpuścił. Nie wiem, dowcip opowiem, ciekawostkę jakąś ze świata, czy choćby po odpowiadam na pytania mi zadane ${ }^{32}$.

Młodzi badacze zastanawiali się jak podziękować, co mogą podarować, czy też planowali powroty do „swoich rozmówców”. Takie spotkania często były postrzegane przez nich, jako impuls do podejmowania walki ze wstydem, nieśmiałością, gdyż wiedzieli już, że może być to wynagrodzone przez niezapomniane i wyjątkowe doświadczenie rozmowy z ciekawym człowiekiem.

Jak już wcześniej zaznaczyłyśmy studenci podczas pobytu na ćwiczeniach terenowych doświadczają różnego rodzaju sytuacji, które pozwalają im zdobyć niezbędną wiedzę i umiejętności przydatne w tym fachu. We wpisach w dziennikach możemy odnaleźć fragmenty, w których dostrzegają oni samych siebie, jako część terenu, który przyszło im badać. Dokonując refleksji nad samymi sobą zauważają jak sposób, w jaki sami postrzegają proces badawczy warunkuje to, co im się przydarza w terenie. W poprzednich akapitach zwróciłyśmy uwagę na zmieniające się nastawienie zależne od napotkanych rozmówców. Dokonywali oni spostrzeżenia, że charakter rozmówcy wpływa również bezpośrednio na ich nastawienie, przez co rozmowa nabierała innych kształtów. Również wraz z upływem czasu

${ }^{32}$ Dziennik: J, 20.03.2012. 
niektórzy studenci podkreślali fakt zwiększonej adaptacji do sytuacji terenowej, nie czuli się już kompletnie obcy - jak intruzi, a czasem wręcz odnajdywali przyjazne gesty występujące w nieformalnych kontaktach, a świadczące o pozytywnym odbiorze wśród badanej społecznej. Z drugiej strony potrafili również zrozumieć siebie, jako „obcych”, innych pojąć, czemu tak są postrzegani. Bardzo ważnym przejawem samoświadomości i zrozumienia roli dzienników w ich zadaniu była analiza własnych posunięć, dostrzeganie błędnych zachowań i refleksja nad przyszłymi działaniami. Dostrzegali na przykład fakt nierówności sytuacji wywiadu, własnej słabej koncentracji czy utraty jej w trakcie toczącej się rozmowy, a także zbytniego przywiązania do wytycznych. Pisząc o problemach i potknięciach rozważali możliwości zaradzenia takim sytuacjom. Tego rodzaju wpisy były również pomocne nam, jako opiekunkom. Stanowiły one często punkt wyjścia do wspólnej dyskusji i przepracowania sytuacji problemowych. Mając do czynienia z wypowiedziami studentów, traktując je, jako środek dydaktyczny, mogłyśmy obserwować sposób oraz czas, w jakim przystosowywali się do pracy w terenie. Systematyczne czytanie ich codziennych zapisków pomagało nam wniknąć w ich sposób myślenia i postrzegania badanego świata, dzięki czemu za pomocą udzielanych porad, wskazówek, mogłyśmy tak pokierować ich poczynaniami, aby w najbardziej efektywny sposób z tego skorzystali. Dzienniki terenowe studentów dały nam szansę bardziej dogłębnego wejścia w cykl uczenia się studentów, w tym przypadku uczenia się terenowego, na większą kontrolę jego czterech etapów.

\footnotetext{
Pierwszy etap to konkretne doświadczenie. (...) Czynnością dominującą w tej fazie cyklu jest odczuwanie. Etap drugi to refleksyjna obserwacja. Uczący się dokonuje wtedy obserwacji i analizy przeżytych doświadczeń. Czynnością dominującą jest obserwowanie. Kolejna faza to abstrakcyjna konceptualizacja. Następuje wyciąganie wniosków z obserwacji i analizy, a następnie konfrontacja uzyskanych wyników $\mathrm{z}$ indywidualną wiedzą teoretyczną lub tworzenie nowej teorii. Dominującą czynnością jest tutaj myślenie. Ostatni etap cyklu to aktywne eksperymentowanie. (...) Dominujące w tej fazie jest działanie ${ }^{33}$.
}

W naszym przypadku oczywistym jest, że pierwszy etap odnosi się do konkretnego, zazwyczaj pierwszego doświadczenia terenowego studentów. Produktem refleksyjnej obserwacji stanowiącej etap drugi są właśnie dzienniki terenowe. Jest to narzędzie dydaktyczne, które przez nas udostęp-

\footnotetext{
${ }^{33}$ A. Baran, dz. cyt., s. 25.
} 
nione i podpowiedziane pozwala uczącym się na bardziej efektywne przepracowanie tego etapu. Na poziomie etapu trzeciego nasila się nasza rola, jako prowadzących ćwiczenia. Dysponując przemyśleniami studentów pomagamy im wyciągać wnioski, oraz kierujemy ich myślenie na tory antropologiczne, starając się, aby uzyskali to, co w slangu etnologów nazywamy etnologicznym spojrzeniem. Wskazujemy kontekst sytuacji, którego nie zauważyli i staramy się całość zinterpretować tak, aby następnym razem już sami potrafili interpretować otaczająca ich rzeczywistość. Następuje przejście do fazy czwartej, czyli działania, które wiąże się z kolejnym doświadczeniem. W ten sposób kumuluje się wiedza i rozwijają umiejętności naszych podopiecznych.

Jednakże nie tylko rozwijanie kompetencji zawodowych było głównym założeniem, które przyświecało nam w pracy ze studentami. Istotnym było dla nas również kształtowanie ich kompetencji społecznych, by nauczyli się ze sobą rozmawiać oraz dzielić doświadczeniem terenowym, tak by nawzajem móc od siebie się uczyć oraz być otwartym na inne sposoby podejścia badawczego czy interpretacji otaczającej rzeczywistości terenowej. Jest to założenie przyjętego przez nas modelu edukacyjnego. Chodziło nam o wytworzenie umiejętności wspólnego działania, dzięki któremu:

(...) dochodzi do stworzenia grupy, do wykreowania relacji wewnętrznych opartych na współdziałaniu i współpracy uczniów/studentów. Mówimy wtedy o tworzeniu kultury wspólnoty, o kształtowaniu nawyków udzielania sobie wsparcia, wchłanianiu norm stymulujących do aktywnego uczenia $\operatorname{się}^{34}$.

Sądzimy, że udało nam się to uzyskać z jednej strony poprzez specyfikę ćwiczeń, czyli wyjazd nieliczną grupą w nowe, odległe miejsce, z drugiej poprzez naszą codzienną, systematyczną pracę z nimi. Zarówno tę w całej grupie, wzmacniającą poczucie wspólnoty w działaniu, w przeżywaniu, w doświadczeniu, jak i tę indywidualną pozwalającą pracować i rozwijać się każdemu w swoim tempie, i rozwiązywać kłopotliwe problemy, o których studenci nie chcieli mówić przy grupie w cztery oczy. Trzeba zdawać sobie sprawę, że tego rodzaju praca dydaktyczna niesie za sobą dodatkowe trudności wynikające z wielości ról, w jakie się wcielają zarówno prowadzący jak i uczestnicy ćwiczeń, a co za tym idzie relacji między nimi zachodzących. Najbardziej oczywistą jest relacja mistrz - uczeń. Mistrz, czyli prowadzący

${ }^{34}$ K. Polak, dz. cyt., s. 94. 
posiadający wiedzę i umiejętności, przekazuje ją uczniowi - studentowi, którego podstawowym zadaniem jest się uczyć. Role te narzucają pewną hierarchiczność i podwładność jednych względem drugi. Występuje jeszcze jeden rodzaj relacji, który można powiązać z tym, że pracę terenową traktuje się jak przepustkę do bycia zawodowcem, kolegą po fachu. W tym rozumieniu mamy do czynienia z relacją badacz - badacz. Gdzie prowadzący, straszy kolega, który już nie jedne badania przeżył i służy radą i swym doświadczeniem młodszemu koledze, który jest dopiero na początku tej drogi. Trzeci rodzaj relacji to badacz - badani, gdzie prowadzący jest badaczem a studenci badanymi. Ten typ relacji charakterystyczny jest przy pracy z dziennikami, ponieważ wtedy badamy sposoby uczenia się i pracy studentów w terenie oraz ich sposoby przystosowywania się do niego. Tak różne i bardzo trudne do pogodzenia rodzaje relacji łączące nas spowodowały, że korzystając z naszych kompetencji antropologicznych potraktowałyśmy studentów, jako badanych i tak do nich podchodziłyśmy, trzymając się wszelkich zaleceń takiej praktyki, czyli dialogiczność, empatii oraz równości. Było to również zgodne z modelem pracy edukacyjnej, który przyjęłyśmy a który jest skoncentrowany:

(...) na studentach, na ich indywidualności, na ich możliwościach, ma służyć ich wzrostowi osobowościowemu, w związku z tym stosowane są metody dialogiczne, bycie „na równi” nauczycieli akademickich i młodzieży studiującej, stosuje się empatię, rezygnuje z liczenia i mierzenia przy użyciu testów, z tym związane jest indywidualizowanie procesu kształcenia $(\ldots)^{35}$.

Takie podejście spowodowało, że studenci bez oporów pisali o różnorodnych problemach, trudnościach napotkanych w terenie. Jak już wcześniej można było zauważyć jednym z głównych dylematów było nawiązywanie kontaktów z potencjalnymi rozmówcami, napotykanie z ich strony niechęci i obojętności często wzmacnianej przez nieśmiałość samych młodych badaczy. Również nastawienie badanych bywało problematyczne podczas trwania rozmowy - zdarzało się, że studenci czuli się lekceważeni i okłamywani podczas badań. $W$ takich przypadkach na kartach swoich dzienników wylewali swoje frustracje i negatywne uczucia. Kolejnym utrudnieniem związanym z relacją między badanym a badaczem był status rozmowy, której współdoświadczali, w której współuczestniczyli. Pojawiały się, więc

${ }^{35}$ St. Palka, dz. cyt., s. 34. 
dylematy związane z tym, co zrobić z informacjami uzyskanymi podczas „luźnych” rozmów, czy też jak i kiedy rozpocząć nagrywanie wywiadu. Jak widać młodzi badacze dostrzegali nieostrą i płynną granicę pomiędzy codziennymi, nieformalnymi kontaktami z badanymi a tym, co staje się już źródłem wiedzy antropologicznej. Ostatnią trudnością, którą tutaj poruszymy jest ta związana z otrzymywaniem od badanych takich historii z ich życia, które wypełnione są silnymi emocjami. Opowieści o problemach, trudnych życiowych sytuacjach, których rozmówcy doświadczali w niektórych wypadkach wywoływało reakcje, na które młodzi badani nie mieli gotowych recept. Zastanawiali się, jak poradzić sobie z płaczem, zarówno rozmówcy jak i swoim, jak zachować się w takiej sytuacji i czy są oni odporni i gotowi na taką dawkę emocji, co obrazują poniższe fragmenty:

W pewnym momencie kobieta rozpłakała się z niewiadomych powodów, a ja czułam się bezsilność, kompletnie nie wiedziałam, co zrobić. Powiedziałam by nie płakała i obróciłam rozmowę w radosną stronę. Po chwili uśmiechnęła się i wyjawiła nam, że parę lat temu miała problem alkoholowy i od 2 lat nie pije. Wtedy poczułam wyrzuty sumienia i bałam się, a właściwie nadal mam takie obawy, że przez poruszenie przez nas jej wspomnień ona znów wypije alkohol. Podczas pożegnania z kobietą miała ochotę ją uścisnąć, lecz bałam się uczynić ten ruch, by nie odebrała tego negatywnie. Dziś poczułam jak ważna jest rozmowa i dialog z drugim człowiekiem ${ }^{36}$.

Sytuacja, kiedy Pan C. Zaczął opowiadać o swojej zmarłej żonie po prostu wyzwoliła we mnie chęć ucieczki. Nie mogę słuchać takich rzeczy, bo to zostanie mi na długo w pamięci, tym bardziej, że to człowiek szczery. Po prostu nie czułem się nawet godny słuchać jego myśli, nie jestem kimś upoważnionym do tak intymnej wiedzy ${ }^{37}$.

Takie sytuacje wywoływały refleksje w młodych badaczach na temat statusu i roli rozmowy w antropologii oraz tego na ile są oni uprawnieni do otrzymywania tego rodzaju historii z życia swoich badanych. Zastanawiali się nad swoimi reakcjami i tym, co mogliby na przyszłość zrobić w podobnych momentach swojej pracy.

Rozważania na temat charakteru pracy antropologa, tego jak przebiega spotkanie z badanymi, co jest pożądane a co wpływa negatywnie, na jakość stanowiły również istotną część zapisków w dziennikach terenowych. Młodzi badacze zauważali, że wywiad może nie być tylko i wyłącznie sformalizowanym uzyskiwaniem informacji, a zaangażowanie i ciekawość obu

${ }^{36}$ Dziennik: R15, dzień 3.

37 Dziennik: R, marzec 2010. 
stron sprawia, że spotkanie badacz - badany może mieć formę dialogu. Wskazywali oni na cechy dobrego rozmówcy takie jak otwartość, rozmowność, ciekawość, gdzie w parze szła również gościnność, która tworząc przyjazną atmosferę wpływała na przebieg spotkania. Z drugiej strony studenci wskazywali takie sytuacje, gdy rozmowa nie była udana przez kontekst, w jakim się odbywała - tutaj bardzo ważne stawało się poczucie komfortu i swobody wypowiedzi - przykładem takich sytuacji są te, gdzie rozmowie przysłuchiwały się niezaangażowane w nią osoby trzecie.

$\mathrm{Na}$ zakończenie chciałybyśmy jeszcze wspomnieć o tych fragmentach, które są swoistymi podsumowaniami doświadczeń zdobytych przez młodych adeptów podczas ich pierwszych badań terenowych. Pojawiają się, więc wpisy dotyczące niesamowitości i wyjątkowości czasu i miejsca, w którym dane było studentom być i przeżywać, pewnych trudności z odnalezieniem się z powrotem po wyjściu z terenu. Doceniają wartość dydaktyczną takiego rodzaju zajęć dostrzegając w sobie zmiany. Wskazują na wzrost otwartości i zaciekawienia otaczającą rzeczywistością, a także na mniejszą nieśmiałość oraz przełamanie wewnętrznych oporów.

W niniejszym tekście starałyśmy się opowiedzieć o pewnym doświadczeniu, a właściwie o pewnych doświadczeniach. Z jednej strony naszym celem było przestawienie doświadczeń studentów etnologii uczestniczących w swoich pierwszych badaniach terenowych, z drugiej ukazanie naszych doświadczeń z pracy ze studentami za pomocą narzędzia dydaktycznego, jakim jest dziennik terenowy. O samym doświadczeniu, jako takim ciężko jest powiedzieć coś konkretnego, jak zauważył J. Clifford jest ono czymś, co badacz posiada lub nie ${ }^{38}$. Wieloznaczność tej kategorii doskonale opisuje Dorota Wolska ${ }^{39}$, dlatego my tutaj ograniczymy się do zaakcentowania kwestii, którą już wcześniej podnosiłyśmy mianowicie, że posiadanie doświadczenia oznacza włączenie badacza w proces badawczy. Jak zauważa Anna Wyka kategorią doświadczenia może stać się:

(...) nie tylko pojęciem, ale także pewną faktycznością, sposobem bycia badacza. Owo przejście, łącznik, między tym, co „teoretyczne” i tym, co „praktyczne” w naszym poczuciu, może tworzyć się wówczas poprzez intencjonalne uczynienie kategorii

${ }^{38}$ J. Clifford, O autorytecie etnograficznym, [w:] Tegoż, Kłopoty z kulturq: dwudziestowieczna etnografia, literatura i sztuka, Wydawnictwo KR, Warszawa 2000, s. 29-63.

39 D. Wolska, Odzyskać doświadczenie. Sporny temat humanistyki współczesnej, Universitas, Kraków 2012. 
„doświadczenia”, które staje się wtedy doświadczaniem. Doświadczanie zyskuje zatem walor narzędzia poznania, nierozerwalnie związanego z podmiotem poznającym, i dlatego współkształtującego użytkowanie przezeń wszelkich innych narzędzi, którymi może dziś dysponować ${ }^{40}$.

Doświadczenie jest obecne od samego początku pracy terenowej, zawierają je pierwsze sporządzane w terenie notatki. 0 tym, że praca etnologa opiera się na pisaniu, już dawno powiedział C. Geertz. Patrząc na interesujące nas doświadczenia mamy do czynienia z dwoma rodzajami tekstu. Pierwszym z nich są opisy doświadczeń studentów zawarte w dziennikach terenowych. Te fieldnotes, bo tak wypadałoby je nazwać, to jak twierdzi Katarzyna Kaniowska:

(...) wszelkie pisane świadectwo, ów pierwszy efekt badań terenowych, względnie surowy tekstualny dowód zetknięcia się badacza z przedmiotem jego obserwacji, doświadczeń, obcowania z ludźmi, obiektami i sytuacjami wybranej kultury. To pierwsze świadectwo stanowi zwykle bazę danych dla późniejszych interpretacji, generalizacji, syntez czy teoretycznego oglądu ${ }^{41}$.

Dla nas zapiski studentów były podstawą do interpretacji ich bytności w terenie, ich sposobów pracy, były narzędziem do doskonalenia sztuki pracy terenowej. To z kolei stanowiło nasze doświadczenie, którego ekspresją jest ten właśnie tekst. Jest on opisem doświadczeń i próbą wyjaśnienie, zrozumienia ich zarazem, ponieważ: „opis zawsze zawieszony jest miedzy doświadczeniem a procedurami teoretycznymi, w szczególności - pomiędzy doświadczeniem a wyjaśnianiem"42.

Naszym zamiarem w niniejszej pracy było prześledzenie owego procesu transformacji doświadczenia terenowego w opis. Opis specyficzny, gdyż tworzony przez studentów po raz pierwszy podczas bytności w terenie. Jak chciałyśmy wykazać dzienniki terenowe nie tylko stanowiły pomocne źródło w pracy dydaktycznej ze studentami, ale były również częścią uzupełniania wiedzy antropologicznej wytwarzanej w terenie - tak były traktowane zarówno przez nas jak i samych autorów.

\footnotetext{
${ }^{40}$ A. Wyka, Badacz społeczny wobec doświadczenia, Wydawnictwo IFiS PAN, Warszawa 1993, s. 5.

${ }^{41}$ K. Kaniowska, Opis - klucz do rozumienia kultury, „Łódzkie Studia Etnograficzne” t. XXXIX, Polskie Towarzystwo Ludoznawcze, Łódź 1999, s. 49.

42 Tamże, s. 17.
} 


\section{BIBLIOGRAFIA}

- Baran A., Komunikacja dydaktyczna, [w:] Wykładowca doskonały. Podręcznik nauczyciela akademickiego, pod. red. A. Rozmusa, Wolters Kluwer Polska Sp. z o.o., Warszawa 2010.

- Bereźnicki F., Organizacyjne formy kształcenia w szkole wyższej, [w:] Wprowadzenie do pedagogiki szkoły wyższej, pod. red. K. W. Jaskota, Oficyna, Szczecin 2006.

- Clifford J., O autorytecie etnograficznym, [w:] Tegoż, Kłopoty z kulturq: dwudziestowieczna etnografia, literatura i sztuka, Wydawnictwo KR, Warszawa 2000.

- Clifford J., Praktyki przestrzenne: badania terenowe, podróże i praktyki dyscyplinujace $w$ antropologii, [w:] Badanie kultury. Elementy teorii antropologicznej. Kontynuacje, pod. red. M. Kempengo, E. Nowickiej, Wydawnictwo Naukowe PWN, Warszawa 2004.

- Hammersley M., Atkinson P., Metody badań terenowych, Wydawnictwo Zysk i S-ka, Poznań 2000.

- Kaniowska K., Heurystyczna wartość wiedzy antropologicznej, [w:] Zanikajace granice. Antropologizacja nauki i jej dyskursów, pod. red. A. Pomiecińskiego, S. Sikory, Biblioteka Telgte, Poznań 2009.

- Kaniowska K., Opis - klucz do rozumienia kultury, „Łódzkie Studia Etnograficzne” t. XXXIX, Polskie Towarzystwo Ludoznawcze, Łódź 1999.

- Kaniowska K., Stare problemy nowej antropologii, „Przegląd Socjologiczny” 2004, nr 1, s. 51-70.

- Kędzierzawski W., Codzienność jako kategoria antropologiczna perspektywie historii kultury, Uniwersytet Opolski, Opole 2009.

- Kubica G., Wstęp, [w:] B. Malinowski, Dziennik w ścisłym znaczeniu tego wyrazu, Wydawnictwo Literackie, Kraków 2002.

- Kuligowski W., Defamiliaryzacja i inne praktyki antropologii bliskości, [w:] Tubylcy własnego świata. W stronę antropologii bliskości, pod. red. tegoż, Polskie Towarzystwo Ludoznawcze, Poznań 2011.

- Kupisiewicz Cz., Podstawy dydaktyki ogólnej, Państwowe Wydawnictwo Naukowe, Warszawa 1978.

- Lofland J., Snow D. A., Anderson L., Lofland L. H., Analiza układów społecznych. Przewodnik metodologiczny po badaniach jakościowych, Wydawnictwo naukowe Scholar, Warszawa 2009.

- Marcus G. E., Użyteczność kategorii uczestnictwa w zmieniających się kontekstach badań terenowych, [w:] Clifford Geertz - Lokalna lektura, pod. red. D. Wolskiej, M. Brockiego, Wydawnictwo Uniwersytetu Jagiellońskiego, Kraków 2003.

- Palka S., Aktualne tendencje $w$ dydaktyce akademickiej, [w:] W poszukiwaniu modelu dydaktyki akademickiej, pod. red. D. Skulicz, Wydawnictwo Uniwersytetu Jagiellońskiego, Kraków 2004.

- Piotrowski E., O osobliwości kształcenia w szkole wyższej, [w:] Wprowadzenie do pedagogiki szkoły wyższej, pod. red. K. W. Jaskota, Oficyna, Szczecin 2006. 
- Polak K., Modele nauczania i możliwości ich wykorzystania w dydaktyce akademickiej, [w:] W poszukiwaniu modelu dydaktyki akademickiej, pod. red. D. Skulicz, Wydawnictwo Uniwersytetu Jagiellońskiego, Kraków 2004.

- Rabinow P., Refleksje na temat badań terenowych w Maroku, Wydawnictwo Marek Derewecki, Kęty 2010.

- Rakoczy M., Wokół zwrotu interpretetywnego, „Przegląd Humanistyczny” 2008, nr 5.

- Sikora S., Odwrócone spojrzenie albo antropologizacja antropologii, [w:] Zanikajace granice. Antropologizacja nauki i jej dyskursów, pod. red. A. Pomiecińskiego, S. Sikory, Biblioteka Telgte, Poznań 2009.

- Silverman D., Prowadzenie badań jakościowych, Wydawnictwo Naukowe PWN, Warszawa 2008.

- Teren w antropologii. Praktyka badawcza we współczesnej antropologii kulturowej, pod. red. T. Bulińskiego, M. Kairskiego, Wydawnictwo Naukowe UAM, Poznań 2011.

- Wolska D., Odzyskać doświadczenie. Sporny temat humanistyki współczesnej, Universitas, Kraków 2012.

- Wyka A., Badacz społeczny wobec doświadczenia, Wydawnictwo IFiS PAN, Warszawa 1993.

- Zawistowicz-Adamska K., Społeczność wiejska. Doświadczenia i rozważania z badań terenowych w Zaborowie, Polskie Instytut Służby Społecznej, Łódź 1948.

\section{FIELD JOURNAL. THE RECORD OF BECOMING A RESEARCHER}

This article is the result of the researches done with the first year students during their first field exercises. Their task was ,inter alia' - writing a field journal, which has become the record of the experience of young anthropologists. In this paper our aim is to analyze and interpret the entries created by students, looking at them from the teaching and anthropological perspective. We are looking at the role of the journal not only as a technique or method of obtaining data for the production of anthropological knowledge but also as a learning tool, producing and developing in young adepts of anthropology necessary skills. What is more journals give us an opportunity to provide a contribution to the discussion with the participants of exercises about the specific field experience which is an important part of anthropological research procedure. 